\title{
Legal politics of the establishment of reserve funds for cemetery
}

\section{Politik hukum pembentukan dana cadangan untuk lahan makam}

\author{
Firman Firdausi", Willy Tri Hardianto, \& Asih Widi Lestari \\ Department of Public Administration, Faculty of Social and Political Sciences, \\ University of Tribhuwana Tunggadewi \\ Address: Jalan Telaga Warna-Block C, Malang, East Java Province, Indonesia 65141 \\ E-mail: firman.firdausi.88@gmail.com
}

Article History: Received 12 June 2021; Accepted 14 February 2022; Published Online 07 March 2022

\begin{abstract}
Malang City as one of the developed cities in Indonesia has a lot of development potential. Development in the city certainly has its own obstacles. Malang City is experiencing growth and an increase in population. This certainly affects all regional developments in this city. One of the obstacles to this development is a legal vacuum in the provision of a cemetery for the public interest which is carried out by local governments based on the Regional Government Law. This study aims to find out the gaps in the authority of local governments in land acquisition through the agenda of Reserve Funds and land acquisition in the public interest. This study used a normative legal method that takes regulatory data from the central to regional governments and analyzed it using legal theory and social analysis. This study concludes that the procurement of cemeteries by the local government can be carried out by means of a limited area of 5 hectares and can be submitted through a reserve fund. A reserve fund is established because large-scale developments cannot be completed in one fiscal year.
\end{abstract}

Keywords: cemetery; legal politics; reserve fund

\begin{abstract}
Abstrak
Kota Malang sebagai salah satu kota yang maju di Indonesia memiliki banyak potensi pembangunan. Pembangunan di kota tentu memiliki kendala tersendiri. Salah satu kendala tersebut adalah adanya kekosongan hukum pada penyediaan lahan makam demi kepentingan umum yang dilaksanakan oleh pemerintah daerah berdasarkan Undang-Undang Pemerintahan Daerah. Studi ini bertujuan untukmengetahui kesenjangan kewenangan pemerintah daerah dalam pengadaan tanah melalui agenda dana cadangan dan pengadaan tanah untuk kepentingan umum. Penelitian ini menggunakan metode yuridis-normatif yang mengambil data-data regulasi dari pemerintah pusat sampai daerah dan menganalisis menggunakan teori hukum dan analisis sosial. Pada penelitian ini didapat hasil bahwa pengadaan lahan makam oleh pemerintah daerah dapat dilaksanakan dengan cara limitatif seluas 5 hektar dan dapat diajukan melalui dana cadangan. Dana cadangan dibentuk karena pembangunan berskala besar tidak dapat diselesaikan dalam satu tahun anggaran.
\end{abstract}

Kata kunci: dana cadangan; lahan makam; politik hukum

\section{Introduction}

Previous studies in this study mostly came from urban planning or civil engineering. Social science is rarely concerned with burial grounds. This research focuses on policy or often referred to as legal politics regarding the procurement of cemeteries. Updating of research is an important aspect so existing research needs to be reviewed as material for comparison and analysis.

One of the several previous studies (Eggener 2010) examined the history of the development of the cemetery paradigm in the United States. The second study (Karel 2015) examined how to determine the location of the cemetery in Malang City. This research combines the science of civil engineering and part of the analysis of regulations that are still in effect. The third study was from Brazil (Motta 2009) which examined changes in the land use of the cemetery which was analyzed based on the culture of the country. His research combined the cultural values of family graves and new forms of development 
into a commercial cemetery. The fourth study (Alam \& Warlina 2019) from social sciences, specifically geography, examines the evaluation of the availability of cemeteries in an area with variables of green open space (GOS) and cemetery criteria (government regulations regarding cemetery requirements). The latest research (Sudiro 2020) was conducted in the Jakarta City area with more complex variables, including the green open space (GOS), the presence of the population, and the technique of overlapping corpses on old corpses. The novelty of this research is that all variables are used, including the availability of land, population growth, Green Open Space, death projections, and the most important focus is the regulation of land acquisition for cemeteries through the reserve fund process.

One of the problems in urban areas is the availability of land (Salindeho 2004). Although the land has been regulated in the Regional Spatial Plan, there are still obstacles, especially in the Green Open Space (GOS) sector. Cemeteries are one part of the green open space. One of the reports stated that the cemeteries in Malang City will be completely full soon with about 20 percent remaining in 2011 (Permata 2011). The Malang City Government plans to allocate reserve funds for the benefit of cemeteries in Malang City.

Regional Reserve Fund is one of the important aspects of regional financing. Reserve Fund can be defined as a fund formed to finance the need for funds that cannot be charged in one fiscal year. The Reserve Fund is established for a specific purpose. The main purpose of the Regional Reserve Fund is to overcome unforeseen circumstances so that there are available costs other than the ongoing Annual Budget. This Reserve Fund is established using a separate account from the Regional Treasury account.

In addition, funding for this kind of activity is generally used for certain developments or projects that require substantial funds that cannot be allocated once in a fiscal year. With the increasing implementation of development, Regional Governments usually use Regional Reserve Funds to carry out development or activities that require large and prioritized budgets.

In City, one of the urgent community service needs is the procurement of cemeteries. This need is based on the growing development of Malang City towards a metropolitan city, population growth, and the number of residential housing developments as a form of developing a city. The limited infrastructure for burial facilities is a matter of concern and needs to be met immediately considering that the available cemeteries are getting narrower and smaller. Therefore, it can result in less-than-optimal services and lead to potential horizontal conflicts.

Cemetery problems in Malang City are not much different from those in other cities. Public Cemetery (TPU) in several locations managed by each village and the Malang City government is getting narrower. Moreover, residents of housing estates who should have their own cemetery mostly choose the nearest cemeteries. Developers should indeed provide cemeteries in every housing complex being built, although in reality, many of their cemeteries are outside the residential area, even choosing the existing TPU. Based on the Malang Government data, the cemeteries are very limited and the addition is not proportional to the increasing population. Based on the results of temporary observations in the field, the management of cemeteries in Malang City is currently still not neatly arranged so the land use is not optimal and creates a haunted and spooky impression. Housing developers still have not provided a burial ground that should be provided as a public facility for housing residents. Housing developers should be able to provide a cemetery with an area of at least $2 \%$ of the housing area (Article 21 Malang City Regional Regulation Number 3 of 2006).

Certainly, cemetery land must be provided as a facility for all levels of society. Some areas already have burial grounds, which consist of government-owned land, village-owned land, family or private land, and cultural-based burial grounds (special burial grounds) such as the guardian"s grave.

Malang City as one of the local governments already has burial areas in several places, including: (1) Sukun Nasrani Cemetery, (2) Sukorejo Cemetery, (3) Kasin Cemetery, (4) Samaan Cemetery, (5) 
Mergan Cemetery, (6) Sukun Gang VII Cemetery, (7) Ngujil Cemetery, (8) Mergosono Cemetery, and (9) Gading Cemetery. The cemetery is a managed land and one of the assets owned by the Malang City Government. In addition to the cemetery managed by the local government, there are several burial grounds that are privately owned by families or managed as special cemeteries.

The obligation of housing developers to provide cemeteries is contained in Law No. 1 of 2011 concerning Housing and Settlement Areas. The housing in question includes a house or housing along with infrastructure, facilities, and public utilities (Article 20 paragraph 2 Juncto Article 32 paragraph 1 of Law Number 1 of 2011), which states that housing development includes: (a) construction of houses and infrastructure, facilities, and public utilities; and/or, (b) improvement of housing quality. As explained above that the cemetery is a means of housing and settlements, then the party who builds the housing is obliged to provide burial facilities.

Urban problems often occur because it turns out that developers or housing developers have not been able to provide cemeteries in the development stage ideally. This is because the allocation of the residential land area is too small. Some housing originates from split land (clusters) that are not managed by legal entities such as developers but by individuals. The number of residents in a housing area at least represents the total area of graves that must be provided in a residential area.

Housing originating from clusters usually uses cemeteries from villages or subdistricts if a member of the community dies. This type of housing only refers to Government Regulation No. 9 of 1987 by including cemetery land, which actually burdens the village government (level II government). In this case, it automatically reduces the allotment of cemetery land that actually belongs to the community. In fact, the Malang City government as of 2019 does not have villages, but only subdistricts. The current position of the village and ward has a significant difference after the enactment of Law Number 23 of 2014 concerning Regional Government and Law Number 6 of 2014 concerning Villages including asset and financial management. Therefore, relying solely on Government Regulation makes the cemetery problem becomes increasingly unsolvable.

Data as of 2014 of the Malang City Government show that not all housing or settlements provide cemetery land, especially those built by private individuals. This cemetery issue must also be evaluated in light of the growing population year by year. This of course will result in new problems in the need for cemeteries in the next few years. Each cemetery issue must be addressed with a solution-oriented plan.

The limitations in regional finances after regional autonomy have opened up space for discretion by local governments regarding program financing that requires relatively large funds. In addition, because the budget period of one fiscal year (1 January - 31 December) is considered "too short", it eventually raises problems for regional fiscal sustainability. The implication of this condition is that local governments are given the authority to establish reserve funds. Explicitly, Article 122 of Government Regulation Number 58 of 2005 concerning Regional Financial Management and Article 63 of Minister of Home Affairs Regulation Number 13 of 2006 concerning Guidelines for Regional Financial Management states that Regional Governments can establish Reserve Funds. The procurement of cemeteries is one of the solutions to problems that have occurred and will occur in the next few years. Land acquisition cannot be carried out without a standard mechanism and in accordance with the provisions of the regulations (the standard mechanism is to use a budget per year). In addition, in terms of the procurement of cemeteries, a large amount of funding is needed. Therefore, the funding process in terms of land acquisition for cemeteries should start as early as possible and achieve sustainability.

The condition of the land in the public cemetery (TPU) managed by the Malang City Government is currently experiencing overload or excess capacity. Even some of the graves had to be overlapped due to the depleted land. However, the number of bodies buried continued to grow. Based on these circumstances, the Malang City Government is currently planning to add land for graves in Malang City. Regarding the plan to mine the cemetery, the Malang City Housing and Settlement Office conducted a 
study on the provision of public burial land. Based on the results of the study, a strategic location for cemeteries must be obtained. the Malang City Housing and Settlement Service had conducted a land survey. For the procurement of cemeteries, the Malang City Government targets a new cemetery area of about \pm 6 hectares. However, this seems to be hampered by the amount of the existing budget.

The funding allocation that will be planned is for three years starting in 2021-2023. The implementation of three years of budgeted funding for land is based on the calculation of the death rate, the existing cemetery area, the projection of Neighborhood Association/Citizen Association (RT/RW), and the Malang City Government Strategic Plan. Procurement of this cemetery can be allocated through a financial process of Reserve Funds. Reserve funds are set aside to accommodate needs that require relatively large funds that cannot be met in one budget year. The arrangement of this reserve fund in the accounting of the Ministry of Home Affairs must include at least a legal umbrella in the form of a Regional Regulation.

Making local regulations here is one of the processes of the legislative drafting flow (Muhammad 2017). This phase is known as legal politics, which is known as policy formulation in other disciplines. This legal politics is the phase where legislation will be made. This opinion is equivalent to that expressed by Wahjono (in Mahfud 1998) that "Legal politics means making policies/setting goals and contents of laws and regulations". Legal politics is detailed by having a political work area that includes the authority of public organs (Hadjon et al. 2010). In this Reserve Fund problem, there is a legal vacuum in the provision of the public cemetery (called TPU).

Table 1.

The division of central and local government affairs for land acquisition for the public interest The division of government affairs in the land sector

\begin{tabular}{cclll}
\hline No. & \multicolumn{1}{c}{ Sub affairs } & Central government & \multicolumn{1}{c}{ Province } & District/city area \\
\hline 1 & Location permission & $\begin{array}{l}\text { Granting of cross- } \\
\text { provincial location } \\
\text { permits }\end{array}$ & $\begin{array}{l}\text { Granting of location } \\
\text { permits across } \\
\text { districts/cities } \\
\text { within one } \\
\text { province }\end{array}$ & $\begin{array}{l}\text { Granting of a location } \\
\text { permit in one } \\
\text { regency/city area }\end{array}$ \\
2 Land procurement & $\begin{array}{l}\text { Implementation of } \\
\text { for public interest }\end{array}$ & $\begin{array}{l}\text { Determination of } \\
\text { the location of land } \\
\text { public interest }\end{array}$ & $\begin{array}{l}\text { acquisition for the } \\
\text { public interest of the } \\
\text { province }\end{array}$ \\
\hline
\end{tabular}

Source: Attachment to Law Number 23 of 2014

Table 1 is one of the attachments to the Law on regional governance. It can be seen that the authority for land acquisition is borne by the central government at least at the provincial level, while this authority is not given in the regions. This is what makes an empirical problem that in reality, the local government really needs land acquisition for the cemetery.

The novelty of this research is that in the field of social sciences, especially legal science, no one has discussed policies on the use of cemeteries in the field of local government. Legal politics (Manan \& Harijanti 2015) means looking at it from the perspective of making rules (material law). Before the law is passed or enters the implementation stage, there is a process that must be passed through legal politics. Legal politics is used in forming a rule that does not yet exist, updating the rule, or revoking an old rule with a new one on the basis of the ambiguity of the applicable article (Asshiddiqie \& Safaat 2011). Based on the problems described, in this case, this study is interested in the Legal Politics of Procurement of Cemeteries which is carried out by the Malang City Government in fulfilling the interests of the community. This study aims to find out the gaps in the authority of local governments in land acquisition through the agenda of Reserve Funds and land acquisition in the public interest. 


\section{Research Method}

The method used in compiling this academic text was normative legal (Marzuki 2002). The normative legal method always focuses on secondary data sources. Secondary data in research can be divided into primary, secondary, and tertiary legal materials. Primary legal materials included statutory regulations related to the Reserve Fund and Cemetery Procurement. Secondary legal materials consisted of books and papers related to the substance of the Reserve Fund, including studies that have been made by the Malang City Government. The tertiary legal materials used included encyclopedias, dictionaries, and information from various related institutions, such as the Ministry of Home Affairs, universities, Statistics Indonesia, and Community Groups in Malang City. Legal research is essentially a postpositivist description flow so it requires data interpretation, both primary data in the form of regulations and secondary data in the form of official, unofficial, and non-rule documents (Marzuki 2017).

In preparation for the academic paper on the Draft Regional Regulation of the Reserve Fund for the Procurement of Cemetery in Malang, the team conducted research using a normative legal approach. The normative legal method is carried out through a literature study that examines (especially) secondary data, both in the form of legislation and research results, assessment results, and other references. Data analysis was conducted using legal theory studies.

\section{Results and Discussion}

\section{Procurement of cemetery land for the public interest of the Malang City Government}

Identification of Land Procurement for Public Interest is basically not given in the Regional Government Law as shown. Through the normative legal method, the researchers found the following results: First, Law Number 6 of 2 of 2012 concerning Land Procurement for Development in the Public Interest. In this law, the procurement of cemeteries is included in the category of public interest. The first point in this law is that the implementation of land acquisition for the public interest must be carried out by the government as regulated in article 6 which reads "Land Procurement for Public Interest is organized by the Government". This definition of land acquisition authority is redefined in the general explanation of this law which reads "The Government and Local Governments guarantee the availability of land for public purposes and their funding". This regulation means that in terms of land acquisition, the available land and funding for the procurement are also the authority of that government, both the central and regional governments. Procurement of cemeteries also refers to this Law that land for burial is included in the category of public interest in Article 10 of this Law. With the position as a lex special, this law actually allows local governments to procure land for the public interest.

The results are concerned with Government Regulation Number 71 of 2012 concerning the Implementation of Land Procurement for Development in the Public Interest. This government regulation is in line with the Law on Land Procurement for Public Interest. Article 3 of this regulation regulates the mechanism for Land Procurement for Regional Governments by mentioning the words: "Agency". Agency or called institution in question is the executive government organs of both central and local governments or other public organs that are competent in the technical implementation of the land acquisition.

The third results are concerned with Presidential Regulation Number 148 of 2015 concerning the Implementation of Land Procurement for Development in the Public Interest. This regulation is the basis for strengthening the procurement of public cemeteries in Malang City. Article 121 reads: "In the context of efficiency and effectiveness, land acquisition for the public interest with an area of not more than 5 (five) hectares, can be carried out directly by the agency that requires the land with the party entitled to it". The formulation in article 121 implies that on the basis of efficiency and effectiveness, the form of delegation of authority to the regions uses the subject of "agencies". First, the principle of effectiveness and efficiency is a principle that is only found in regional government, which is in 
article 58 of the Law on Regional Government. Second, based on the principle of regional autonomy, if the affairs are more effectively and efficiently managed by the regional government, then these affairs can become the authority of the regional government. Third, article 237 of the Law on effective and efficient Regional Government is set forth in the form of a Regional Regulation (this regulation is called PERDA). Therefore, this presidential regulation allows the procurement of land for public cemeteries (public interest) for local governments, in this case, Malang City, which is limited to no more than 5 hectares.

Forth results are concerned with East Java Governor's Regulation Number 6 of 2016 concerning Guidelines for Land Acquisition Preparation for Development in the Public Interest. The Governor's Regulation reads the same as Article 121 of Presidential Regulation Number 148 of 2015 which harmonizes development in the public interest for local governments. The provisions of the governor's regulation and presidential regulation explain that in providing public interest, the land acquisition must pay attention to the suitability of the Spatial and Regional Planning (RTRW), synchronization of land values using land price appraisers, and no need for location determination.

The relationship between the central and regional government is something that is widely discussed because, in practice, this problem often creates a spanning of interest between the two government units (Huda 2015). The relationship between both governments occurs as a result of the scattering of state and government administration or the distribution of power into smaller government units which in practice can be realized in various forms. The problem of the relationship of authority between the central and regional governments in the context of the widest possible autonomy is actually a discussion of the contents of regional households which in the perspective of regional government law is commonly called regional household affairs (huishounding). The model of central and local governments, citing the opinion of Clarke and Stewart in a book entitled Central Monitoring of the Regions in Huda (2003), can be divided into three, including (1) The Relative Autonomy Model, which provides relatively large freedom to local governments while respecting the existence of the central government. The emphasis is on granting local government's freedom of action within the framework of powers/duties and responsibilities that have been formulated by laws and regulations, (2) The Agency Model, a model in which the local government does not have significant power so that its existence is seen as an agent of the central government whose job is to carry out the policies of the central government. Because in this model various control mechanisms are prominent, local revenue is not important in that the regional financial system is dominated by assistance from the central government, (3) The Interaction Model, is a form of a model in which the existence and role of local governments are determined by the interaction between the central and local governments.

In large organizations that adhere to the notion of democracy, centralization, and deconcentration, the principle of decentralization is also implemented (Sirajuddin \& Winardi 2015). Through decentralization, the formation and implementation of policies spread across various levels of substantial government. This principle serves to create diversity in the administration of government in accordance with the conditions and potential of the community. In other words, the presence of decentralization is nothing more than to accommodate the diversity of the community so that structural and political variations are realized to channel the aspirations of the local community (Wignjoseobrotto 2008). People's aspirations are manifested in the form of public interest which is also one of the principles in the administration of government.

The relationship of authority, among others, relates to the way the administration of government affairs is divided or the way regional household affairs is determined. The use of the term "local household" is crucial to show the independence and freedom of the region to regulate and manage its own regional interests. Broad autonomy usually starts from the principle that all government affairs become regional household affairs, except those determined by the central government. In a modern state, especially when it is associated with the notion of the welfare state, the number of government affairs cannot be identified (Fakrulloh 2014). 
The regional household system is an arrangement concerned with ways of dividing authority, duties, and responsibilities to regulate and manage government affairs between the center and the regions. One of the manifestations of this division is that the regions will have a number of government affairs either on the basis of submission or recognition or those given as regional household affairs (Azhari 2014).

The Reserve Fund is one of the household affairs in the financial sector which is given to the regions to be used in regulating their own autonomy. As a function of government, "local household affairs" are not only about the interests of the community (public striped) but also individual (individual striped) and government interests, such as organizational structure, division of tasks among government positions, and so on (Sukriono 2013).

Measuring cemeteries basically also refers to existing policies (Sudiro 2020). First, it is seen from a spatial perspective. The national and especially regional stages have their own spatial plans. The achievement of the cemetery can be measured from the Green Open Space. If the amount of green open space is not in accordance with the planning (less than the standard of spatial planning), then the region has an obligation to increase it. The procurement of a cemetery is basically able to increase the number of Green Open Spaces even though its designation is not in public spaces such as parks.

Based on the foregoing, it can be concluded that household affairs include the interests of individuals, authorities, and the community, including the integration of these three interests in their implementation or in fulfillment so that there is no gap between one interest and another (Sumardjono 2008). This means that the interests of individuals, society, and the ruler or government must always be in harmony, balance, and complement each other (1) Basically, from the legal basis analyzed above, local governments are given limited authority with the following provisions, (2) The area is not more than 5 hectares. It still causes debates because there is no budget year limit so that it can be done per fiscal year, (3) Pay attention to the suitability of the area's RT/RW, (4) No location determination, (5) Using the results of the appraisal service appraiser.

Based on the theory of constitutional law, there are reasons why local governments are not given the authority to handle land acquisition even though it is public interest. The Law on Regional Government 2014 is categorized as embracing two ways of transferring authority (Sirajuddin et al. 2016), including open-end arrangement and Ultra Vires Doctrine (Sirajuddin et al. 2016). The Ultra Vires Doctrine causes the division of regional and central government affairs to be very detailed. The reason that land acquisition arrangements were not given to local governments was that it contained "issues that have serious ecological impacts so that the delegation of authority only extends to the provincial level".

\section{Establishment of a reserve fund for public cemetery}

The first stage before the establishment of the Reserve Fund is to identify the existing condition of the cemetery in Malang City. The urgency of land acquisition for the cemetery will be seen in the existing condition of the land and the projected number of deaths. This, of course, does not include conditions during the COVID-19 period, where the number of deaths was higher than the projected normal death.

Based on the calculation of the projected death rate, the results for the entire Malang City in 2019 are 3,127 people and 4,612 people at the end of the 2023-2024 planning year. This number is then mapped based on a detailed spatial plan (RDRT) which is divided into several areas or called BWP. Based on the BWP area, the highest death rate in 2019 was North Malang BWP of 727 people. Meanwhile, at the end of the 2023 planning year, the highest death rate is in Northeast Malang BWP with 1,234 deaths.

The need for TPU based on the projected death rate for the period 2019-2023 is based on the number of residents divided into each BWP in Malang City per year, by looking at the population conditions from 2014 to 2018. It was sourced from data from the Department of Population and Civil Registry of Malang City. 
Table 2.

Projection of the death rate in all BWP in Malang City every year

\begin{tabular}{|c|c|c|c|c|c|c|c|c|}
\hline BWP & Variable & 2017 & 2018 & 2019* & $2020^{*}$ & $2021^{*}$ & $2022^{*}$ & $2023^{*}$ \\
\hline \multirow{3}{*}{$\begin{array}{l}\text { West } \\
\text { Malang } \\
\text { BWP }\end{array}$} & $\begin{array}{l}\text { Total } \\
\text { population }\end{array}$ & 131,646 & 132,769 & 135,923 & 139,077 & 142,232 & 145,386 & 148,54 \\
\hline & $\begin{array}{l}\text { Number of } \\
\text { deaths }\end{array}$ & 630 & 783 & 459 & 513 & 569 & 632 & 633 \\
\hline & $\begin{array}{l}\% \text { death } \\
\text { rate }\end{array}$ & 0.48 & 0.59 & 0.34 & 0.37 & 0.40 & 0.43 & 0.43 \\
\hline \multirow{3}{*}{$\begin{array}{l}\text { Center } \\
\text { Malang } \\
\text { BWP }\end{array}$} & $\begin{array}{l}\text { Total } \\
\text { population }\end{array}$ & 91,835 & 91,379 & 96,348 & 101,317 & 106,287 & 111,256 & 116,225 \\
\hline & $\begin{array}{l}\text { Number of } \\
\text { deaths }\end{array}$ & 439 & 539 & 325 & 374 & 425 & 484 & 495 \\
\hline & $\begin{array}{l}\% \text { death } \\
\text { rate }\end{array}$ & 0.48 & 0.59 & 0.34 & 0.37 & 0.40 & 0.43 & 0.43 \\
\hline \multirow{3}{*}{$\begin{array}{l}\text { Southeast } \\
\text { Malang } \\
\text { BWP }\end{array}$} & $\begin{array}{l}\text { Total } \\
\text { population }\end{array}$ & 179,366 & 181,31 & 185,275 & 189,24 & 193,204 & 197,169 & 201,134 \\
\hline & $\begin{array}{l}\text { Number of } \\
\text { deaths }\end{array}$ & 858 & 1.069 & 626 & 698 & 772 & 858 & 857 \\
\hline & $\begin{array}{l}\% \text { death } \\
\text { rate }\end{array}$ & 0.48 & 0.59 & 0.34 & 0.37 & 0.40 & 0.43 & 0.43 \\
\hline \multirow{3}{*}{$\begin{array}{l}\text { Northeast } \\
\text { Malang } \\
\text { BWP }\end{array}$} & $\begin{array}{l}\text { Total } \\
\text { population }\end{array}$ & 189,064 & 189,968 & 209,852 & 229,736 & 249,62 & 269,504 & 289,388 \\
\hline & $\begin{array}{l}\text { Number of } \\
\text { deaths }\end{array}$ & 904 & 1.12 & 709 & 848 & 998 & 1.172 & 1.234 \\
\hline & $\begin{array}{l}\% \text { death } \\
\text { rate }\end{array}$ & 0.48 & 0.59 & 0.34 & 0.37 & 0.40 & 0.43 & 0.43 \\
\hline \multirow{4}{*}{$\begin{array}{l}\text { East } \\
\text { Malang } \\
\text { BWP }\end{array}$} & $\begin{array}{l}\text { Total } \\
\text { population }\end{array}$ & 77,339 & 78,126 & 83,205 & 88,284 & 93,362 & 98,441 & 103,52 \\
\hline & $\begin{array}{l}\text { Number of } \\
\text { deaths }\end{array}$ & 370 & 461 & 281 & 326 & 373 & 428 & 441 \\
\hline & $\begin{array}{l}\% \text { death } \\
\text { rate }\end{array}$ & 0.48 & 0.59 & 0.34 & 0.37 & 0.40 & 0.43 & 043 \\
\hline & $\begin{array}{l}\text { Total } \\
\text { population }\end{array}$ & 206,323 & 207,442 & 215,287 & 223,132 & 230,978 & 238,823 & 246,668 \\
\hline \multirow{2}{*}{$\begin{array}{l}\text { North } \\
\text { Malang } \\
\text { BWP }\end{array}$} & $\begin{array}{l}\text { Number of } \\
\text { deaths }\end{array}$ & 987 & 1.223 & 727 & 824 & 924 & 1.039 & 1.051 \\
\hline & $\begin{array}{l}\% \text { death } \\
\text { rate }\end{array}$ & 0.48 & 0.59 & 0.34 & 0.37 & 0.40 & 0.43 & 0.43 \\
\hline \multirow[t]{3}{*}{ Amount } & $\begin{array}{l}\text { Total } \\
\text { population }\end{array}$ & 875,573 & 880,994 & 925,89 & 970,786 & $1,015,683$ & $1,060,579$ & $1,105,475$ \\
\hline & $\begin{array}{l}\text { Number of } \\
\text { deaths }\end{array}$ & 4,188 & 5,195 & 3,127 & 3,583 & 4,061 & 4,613 & 4,712 \\
\hline & $\begin{array}{l}\% \text { death } \\
\text { rate }\end{array}$ & 0,48 & 0,59 & 0,34 & 0,37 & 0,40 & 0,43 & 0,43 \\
\hline
\end{tabular}

Source: Malang City Environment Department (2019) 
The death rate from 2014 to 2018 becomes the basis to calculate the average death rate in Malang City for each BWP in Malang City per year for the projected death rate from 2019 to 2023. For more details, see the following Table 2 .

The projected amount of land requirement for Public Cemetery (TPU) according to the projected death rate is based on the Regulation of the Minister of Public Works Number 05/PRT/M/2008. The ministerial regulation regulates, among other things, the standard area of cemeteries, cemetery facilities, and infrastructure, as well as the composition of Green Open Spaces that must be owned by public cemetery complexes.

Table 3.

TPU area needs based on projected death rates every year

\begin{tabular}{llccccc}
\hline \multicolumn{1}{c}{ BWP } & \multicolumn{1}{c}{ Variable } & $\mathbf{2 0 1 9}$ & $\mathbf{2 0 2 0}$ & $\mathbf{2 0 2 1}$ & $\mathbf{2 0 2 2}$ & $\mathbf{2 0 2 3}$ \\
\hline \multirow{4}{*}{ West Malang BWP } & Number of deaths (person) & 459 & 513 & 569 & 632 & 633 \\
& Cemetery standard & $3.3 \mathrm{~m}^{2}$ & $3.3 \mathrm{~m}^{2}$ & $3.3 \mathrm{~m}^{2}$ & $3.3 \mathrm{~m}^{2}$ & $3.3 \mathrm{~m}^{2}$ \\
& Cemetery Need (Ha) & 0.1515 & 0.1694 & 0.1877 & 0.2087 & 0.2090 \\
Center Malang & Number of deaths (person) & 325 & 374 & 425 & 484 & 495 \\
BWP & Cemetery standard & $3.3 \mathrm{~m}^{2}$ & $3.3 \mathrm{~m}^{2}$ & $3.3 \mathrm{~m}^{2}$ & $3.3 \mathrm{~m}^{2}$ & $3.3 \mathrm{~m}^{2}$ \\
& Cemetery Need (Ha) & 0.1074 & 0.1234 & 0.1402 & 0.1597 & 0.1635 \\
Southeast Malang & Number of deaths (person) & 626 & 698 & 772 & 858 & 857 \\
BWP & Cemetery standard & $3.3 \mathrm{~m}^{2}$ & $3.3 \mathrm{~m}^{2}$ & $3.3 \mathrm{~m}^{2}$ & $3.3 \mathrm{~m}^{2}$ & $3.3 \mathrm{~m}^{2}$ \\
& Cemetery Need (Ha) & 0.2065 & 0.2305 & 0.2549 & 0.2830 & 0.2829 \\
Northeast Malang & Number of deaths (person) & 709 & 848 & 998 & 1.172 & 1.234 \\
BWP & Cemetery standard & $3.3 \mathrm{~m}^{2}$ & $3.3 \mathrm{~m}^{2}$ & $3.3 \mathrm{~m}^{2}$ & $3.3 \mathrm{~m}^{2}$ & $3.3 \mathrm{~m}^{2}$ \\
& Cemetery Need (Ha) & 0.2798 & 03294 & 0.3868 & 0.4071 & 0.2798 \\
East Malang BWP & Number of deaths (person) & 326 & 326 & 373 & 428 & 441 \\
& Cemetery standard & $3.3 \mathrm{~m}^{2}$ & $3.3 \mathrm{~m}^{2}$ & $3.3 \mathrm{~m}^{2}$ & $3.3 \mathrm{~m}^{2}$ & $3.3 \mathrm{~m}^{2}$ \\
& Cemetery Need (Ha) & 0.1075 & 0.1232 & 0.1413 & 0.1456 & 0.1075 \\
North Malang BWP & Number of deaths (person) & 824 & 824 & 924 & 1.039 & 1.051 \\
& Cemetery standard & $3.3 \mathrm{~m}^{2}$ & $3.3 \mathrm{~m}^{2}$ & $3.3 \mathrm{~m}^{2}$ & $3.3 \mathrm{~m}^{2}$ & $3.3 \mathrm{~m}^{2}$ \\
& Cemetery Need (Ha) & 0.2718 & 0.3048 & 0.3428 & 0.3470 & 0.2718 \\
\hline \multirow{2}{*}{ Total } & Number of deaths (person) & 3.583 & 3.583 & 4.061 & 4.613 & 4.712 \\
& Cemetery standard & $3.3 \mathrm{~m}^{2}$ & $3.3 \mathrm{~m}^{2}$ & $3.3 \mathrm{~m}^{2}$ & $3.3 \mathrm{~m}^{2}$ & $3.3 \mathrm{~m}^{2}$ \\
\hline Average Total & Cemetery Need (Ha) & 10.321 & 11.825 & 13.401 & 15.223 & 15.551 \\
Cemetery in five & & 6.6320 & & & & \\
years (Ha) & & Ha & & & & \\
\hline & & & & &
\end{tabular}

Source: Malang City Environment Department (2019)

Table 3 is a comparison with the previous table (projected mortality rate) with the addition of the variable of availability of cemetery in each area in Malang City and the size of the graves according to regulations. The results analyzed through the table found that Malang City needs about 6 hectares per year. This is of course limited by the provisions on land acquisition for the public interest of 5 hectares per year which can be provided for the regions. The procurement of land for this cemetery is all inclusive (general) even though its management is managed according to religion. Therefore, there is no emphasis on a particular tribe or certain religion such as the Chinese cemeteries.

The characteristics of cemeteries in urban areas such as Malang do not only refer to the availability of the government but those provided by housing estates (Karel 2015). The urban problem that occurs is the number of rogue developers who deliberately eliminate this obligation by building housing in the form of clusters. Whereas in terms of obligations, housing provides at least $2 \%$ of the total land area for burial. 
Compliance with regional policies is analyzed by formulating a policy review related to the plan to determine the location of the TPU. The regional policies used are the RT/RW of Malang City and the RDTR of each BWP. This suitability strengthens the basis that the location is in accordance with the spatial and regional plan of Malang City.

Table 4.

Results of identification of cemetery land conditions in Malang City

\begin{tabular}{|c|c|c|}
\hline Area & Non-government $<1,5$ ha, Government: & - \\
\hline $\begin{array}{l}\text { Land use and total } \\
\text { population }\end{array}$ & Cemetery and Total Society & $\begin{array}{l}\text { The formula for determining } \\
\text { the required area: Standard } \\
\text { total population: } 3.3 \mathrm{~m}^{2}= \\
\text { required standard area. }\end{array}$ \\
\hline Problems & $\begin{array}{l}\text { 1) Some are used for street vendors, } \\
\text { 2) Buildings to live in, 3) Warehouse, 4) } \\
\text { Vegetation type: already exists, but needs } \\
\text { proper arrangement and determination of } \\
\text { vegetation type }\end{array}$ & - \\
\hline Management & Government and Individual & $\begin{array}{l}\text { Area: currently the cemetery } \\
\text { is } 377,292 \mathrm{~m}^{2} \text { and the } \\
\text { percentage of funerals is } \\
93 \% \text {, leads to the following } \\
\text { results: } 1 \text { ) Out of capacity, } 2 \text { ) } \\
\text { Only local people and does } \\
\text { not accommodate the poor } \\
\text { city community in general }\end{array}$ \\
\hline
\end{tabular}

Source: Malang City Environment Department (2019)

Table 4 presents the result of the analysis on the problem inventory list at the department. The variable that is needed is the area of the cemetery according to the standards of the Malang City regulations regarding the use of cemeteries. In addition, other variables include the provision of facilities and infrastructure and the comparison of ownership of the cemeteries. Based on the table and calculation, the area of the cemeteries that is currently used is more than 90 percent. Therefore, in the near future, the number of bodies will not be accommodated and will cause overlapping graves. This situation, of course, does not include the time of the COVID-19 incident which resulted in mass deaths.

Based on the calculation of the number of cemeteries need from the projected death rate, the result shows that $6.6320 \mathrm{Ha}$ is needed for the 2019-2023 period or five years of planning. Specifically, 1.1825 $\mathrm{Ha}$ is required in 2019, 1.3401 $\mathrm{Ha}$ in 2020, 1.5223 $\mathrm{Ha}$ in 2021, 1.5551 Ha in 2022, and $1.1825 \mathrm{Ha}$ in the final year of planning in 2023. If a development plan is determined within five years of planning, it is necessary to stipulate a budget in three years through a reserve fund.

The Reserve Fund is recorded in a separate account in the name of the regional government reserve fund managed by the Regional General Treasurer (BUD). Reserve Fund Management is the placement of Reserve Funds before they are used according to their designation, in a portfolio that provides fixed returns with low risk. The establishment of Reserve Funds has been carried out by several cities/regencies to fund several government programs such as the construction of hospitals or general elections. In Malang City, Reserve Funds have been carried out in the process of implementing the election of the mayor of Malang City in 2011 which was ratified through the City Regional Regulation Number 9 of 2011.

Based on the 2017-2018 Realization of the Revenue and Expenditure Budget report of Malang City, it is known that the government funding has a surplus of funds in the form of excess budget financing (SILPA). Budgeting Reserve Funds for cemetery needs can use the SILPA budget which is obtained 
from elements of regional original income such as levies on revenues from separated regional wealth management and other legitimate sources of PAD, non-tax revenue sharing funds, and grant funds. Based on the calculation of the budgeting of the cemetery Reserve Funds obtained from the funding posts above, it does not exceed the amount of the SILPA budget in the same year.

From the 2017-2018 Revenue and Expenditure Budget Realization report, it is known that the Malang City Government funding has a surplus of funds in the form of excess budget financing (SILPA) of IDR $489,523,033,616.78$ of the revenue budgeting surplus that was reduced by net spending and financing. For allocation for the budgeting of Reserve Funds for cemetery needs, the SILPA budget can be used which is obtained from elements of regional original income such as levies on revenues from separated regional wealth management and other legitimate sources of PAD, non-tax revenue sharing funds, and grant funds.

When viewed in terms of regional financial capacity, it can be seen that for the period 2014-2018, funding posts for cemetery Reserve Funds ranged from IDR 150,000,000,000 - 280,000,000,000. Of course, this is a theoretical calculation based on the reference on Law Number 33 of 2004 concerning Central and Regional Financial Balance and Government Regulation Number 12 of 2009 concerning Regional Financial Management. For ideal conditions, the budget for cemeteries is around IDR 100,000,000,000 (one hundred billion rupiah) in the budget. This figure is relatively flexible with the necessary land acquisition capabilities and coordination between stakeholders who have authority such as the Housing and Settlement Areas Office, the Environment Agency, the Research and Development Planning Agency, the Regional Financial and Asset Management Agency, the Legal Department, and the City Regional Secretariat Organization is required.

Comparison in several countries in the world. First, there is still the concept of a kinship cemetery in Brazil. This certainly makes it difficult for the government to be able to regulate the spatial planning of cemeteries and Green Open Spaces. Brazil began to study the concept of burial in an individual direction (Motta 2009). This individual-based funeral has a detrimental social impact because of the wide social class distance. Individual-based funerals were actually used by the rich nobility, certain orders, and elite groups in the country. Meanwhile, in Indonesia, family-based burials are still identical with private burial grounds and the government uses equal rules for social and individual strata for public funerals. Each grave is given an area based on the rules of $3.3 \mathrm{~m} 2$ including the distance between the graves. From a sociological perspective, a secular perspective views citizenship as a mediator or key. Citizenship as a secular institutional arrangement mediates between privatized religious discourse and public issues (Turner 1991). The idea of citizenship does not only have an inner connection with religion in conceptual historical terms. Therefore, citizenship scholars need to make use of religious sources in search of new ones. Changes in the need for cemeteries on a national scale can be acquired by the government through this citizenship basis. Tribes, religions, and individuals are centrally regulated in the use of cemeteries through government policies.

Second, the United State of America, according to its individualist ideology, adheres to one grave of one person. Although historically, there have been mass burials in one place caused by certain conditions such as the war in the Middle Ages (Eggener 2010). In that country, the cemetery already has developed management. This is evidenced by the existence of cemeteries that are handed over to the private sector, of which some of them are commercialized. In this regard, the flow of orientalism in Indonesian society is very strong (Turner 1994). This flow in the criticism of social science has become one of the antitheses of the western world's schools which dominate the mindset of government policies. Orientalism and Islamic religion as conceptualized by Turner appear in several cemetery arrangements that regulate burial procedures and sometimes come to respect for a particular ethnicity or tribe, but only implemented in a cemetery belonging to that ethnicity. 


\section{Direction and scope of legal politics for establishing a reserve fund for Malang City cemetery}

The scope or target to be achieved in the draft City Regional Regulation is the achievement of a budget originating from Reserve Funds and used to finance the procurement of cemeteries for the public interest. The target is expected to be achieved within three fiscal years using Reserve Funds. Expansion of grave land that has an impact with the addition of green open space will be the expected target in the use of this Reserve Fund.

The direction of the regulation that will be carried out is to provide a legal basis for financial management officials and officials related to the procurement of cemeteries. The direction of this arrangement is related to the disbursement and management of Reserve Funds for the procurement of cemeteries. The direction of regulation begins in the year of implementation and ends in the third year of planning in line with the strategic plan of the Malang City Government.

The direction of this regulation is about planning the use of Reserve Funds that will be used to finance the procurement of public cemeteries. The establishment of reserve funds is based on statutory regulations, of funds originating from the rest or allowance for regional finances, except: (1) Special Allocation Fund (called DAK), (2) Regional Loans, and (3) other revenues whose use is restricted to certain expenditures based on the provisions of laws and regulations.

The plan for the establishment of this Reserve Fund is planned and established in the 2020 fiscal year and above to be implemented in a 5-year period. This Reserve Fund can be budgeted and disbursed within a period of 5 years of funding with a per-year budget system by following the needs of cemetery planning. If at the end of the fiscal year there is still an unabsorbed budget balance, then according to the regulations, the remaining funds will be returned to the regional general treasury account.

The ratification of this plan needs to be in the form of a regional regulation which is then ratified by the executive and the Malang City legislature. This is to lock the sustainability of the program and the need for cemeteries which is getting more and more urgent. The finalization of this legal policy is to conduct a public test of the readiness of legal politics (policy draft) of Reserve Funds for cemeteries before it is legalized (Setiyono 2004). This FGD is needed to accommodate all forms of community aspirations in meeting the needs of cemeteries through Reserve Funds. This FGD system is actually a development of the science of forming laws and regulations that are more directed towards public openness since postreform (Marijan 2010).

The state essentially has two functions, including the formation and application (implementation) of law, and these functions are not coordinated but are arranged in stages, namely super-ordination and sub-ordination (Hans 2008). Furthermore, it is impossible to define the boundaries that separate these functions from each other because the difference between the formation and application of the law that underlies the dualism of legislative and executive powers (in a broad sense) is only relative; most of the actions of the state are simultaneously acts of forming and enforcing laws. Both the central and the regional governments of these two organs are ordinative and sub-ordinative. Therefore, these two organs have the same function but are limited by the sub-ordinating nature (Wasistiono \& Wiyoso 2009).

Regional regulations can be initiated from the executive and legislative branches through legislation programs (Zuhro et al. 2010). Multi-year reserve funds have become a trend in bridging very large funds with the nature of multi-year programs or projects. Reserve funds are also required to be in the form of legal products. Usually, regions use this Reserve Fund to fund regional head elections, strategic projects, and other multi-year programs. The legal vacuum here becomes a novelty in legal science in Indonesia to form new rules based on the principle of public interest. The Ultra Vires Doctrine principle is actually used in applying the precautionary principle in government. However, in practice in a civil law legal system country such as Indonesia, the law must be updated frequently. Through Presidential Regulation Number 148 of 2015, this legal void can be filled because the presidential strata are higher 
than the regions, although on the other hand there are old laws that are still in effect covering the regional authority to acquire land. This presidential regulation also provides limited conditions for regions to be able to acquire land for the public interest.

\section{Conclusion}

Based on normative legal research, this study found a gap between das sollen in the form of a legal vacuum on land acquisition for local governments and das sollen where there are rules made by the president for the benefit of local governments that apply for land acquisition on a limited basis. The normative legal-based research was used to find elements of a legal vacuum, overlapping laws, or blurring of legal norms. The procurement of cemeteries is the most crucial thing in urban areas, including Malang City. The cemeteries used in Malang City have reached 90 percent and there are overlapping bodies, with conditions before the COVID-19 pandemic. Another problem that was answered was locking the sustainability of the land acquisition through the Reserve Fund agenda. The Reserve Fund was used due to the limited APBD allocation along with the short budget year, and the limited area of land proposed.

Through the principle of public interest and the mechanism of Reserve Funds, the procurement of cemeteries can be carried out with limited conditions of no more than 5 (five) hectares per year. If the land exceeds 5 (five) hectares, it can be allocated into a multi-year program and agreed (by the regional executive and legislature) in the form of a regional regulation on Reserve Funds. This agreement is in the form of a legal product that is contained in a regional regulation that regulates Reserve Funds. This regulation is used to lock the consistency of procurement, the area of land that can be purchased annually, and the budget allocation that can be used annually.

\section{References}

Alam MFI \& Warlina L (2019) Evaluasi penyediaan tempat pemakaman umum (TPU) di Kota Bandung. Jurnal Wilayah dan Kota 6 (1):14-21. https://doi.org/ 10.34010/JWK.V6I01.2452.

Asshiddiqie J \& MA Safaat (2011) Teori Hans Kelsen Tentang Hukum. Jakarta: Konstitusi Press.

Azhari AF (2014) Rekonstruksi Tradisi Bernegara dalam UUD 1945. Yogyakarta: Genta Publishing.

Eggener K (2010) Building on burial ground. Places Journal, December. https://placesjournal.org/ article/building-on-burial-ground/?cn-reloaded $=1$.

Fakrulloh ZA (2014) Politik Hukum Otonomi Daerah. Jakarta: Raja Grafindo Persada.

Hadjon P, Lotulung PE, \& Laica (2010) Hukum Administrasi dan Good Governance. Jakarta: Penerbit Universitas Trisakti.

Hans K (2008) Teori Hukum Murni: Dasar-Dasar Ilmu Hukum Normatif. Bandung: PT Rineka Cipta.

Huda N (2003) Pengawasan pusat terhadap daerah (kajian terhadap peraturan daerah "bermasalah"). Jurnal Hukum Ius Quia Iustum 10 (23):28-45. https://doi.org/10.20885/iustum.vol10.iss23.art2.

Huda N (2015) Hukum Pemerintahan Desa dalam Konstitusi Indonesia sejak Kemerdekaan hingga Era Reformasi. Malang: Setara Press.

Karel WYC (2015) Penentuan lokasi makam estate di kota Malang. Thesis, Institut Teknologi Nasional, Malang.

Mahfud MD (1998) Politik Hukum di Indonesia. Jakarta: Raja Grafindo Persada.

Malang City Environment Department (2019) Final Report of Academic Paper, Design of Regional Regulations for Procurement Reserves Malang City Gravel Land. Malang: Unpublished Report.

Manan B \& Harijanti SD (2015) Memahami Konstitusi Makna dan Aktualisasi. Jakarta: Raja Grafindo Persada.

Marijan K (2010) Sistem Politik Indonesia, Konsolidasi Demokrasi Pasca Orde Baru. Jakarta: Kencana. Marzuki (2002) Metodologi Riset. Yogyakarta: PT. Prasetia Widya Pratama.

Marzuki PM (2017) Penelitian Hukum. Jakarta: Kencana.

Motta A (2010) Brazilian cemeteries, tomb styles, and their associated social processes. Revista Brasileira de Ciências Sociais. http://socialsciences.scielo.org/scielo.php?script=sci_arttext\&pid=S010269092010000100007\&lng=en\&tlng=en. 
Muhammad SI (2017) Pengantar Ilmu Hukum. Jakarta: Kencana.

Permata TJ (2011) Lahan makam di Kota Malang tinggal 20 Persen. Tribun News, 22 June. [Accessed 05 November 2020]. https://surabaya.tribunnews.com/2011/06/22/lahan-makam-di-kota-malangtinggal-20-persen.

Salindeho J (2004) Masalah Tanah dalam Pembangunan. Jakarta: Sinar Grafika.

Setiyono B (2004) Birokrasi dalam Perspektif Politik \& Administrasi. Semarang: Pukodak FISIP UNDIP. Sirajuddin \& Winardi (2015) Dasar-Dasar HTN Indonesia. Malang: Setara Press.

Sirajuddin, Fatkhurohman, \& Zulkarnain (2016) Legislative Drafting: Pelembagaan Metode Partisipatif dalam Pembentukan Peraturan Perundang-Undangan. Malang: Setara Press.

Sirajuddin, Ibrahim A, Hadiyantina S, \& Haruni CW (2016) Hukum Administrasi Pemerintahan Daerah. Malang: Intrans Publishing.

Sudiro D (2020) Analisis ketersediaan lahan untuk tempat pemakaman umum (studi kasus Tempat Pemakaman Umum Semper, Kelurahan Semper Timur, Kecamatan Cilincing, Kota Administrasi Jakarta Utara). Jurnal Geografi, Geografi dan Pengajarannya 18 (2):105-118. https://doi. org/10.26740/jggp.v18n2.p105-118.

Sukriono D (2013) Hukum, Konstitusi dan Konsep Otonomi. Malang: Setara Press.

Sumardjono MSW (2008) Tanah dalam Perspektif Hak Ekonomi Sosial dan Budaya. Jakarta: Kompas.

Turner B (1991) Religion and Social Theory. London: Sage Publication.

Turner B (1994) Orientalism, Postmodernism, and Globalism. London: Routledge.

Wasistiono S \& Wiyoso Y (2009) Meningkatkan Kinerja Dewan Perwakilan Rakyat Daerah. Bandung: Fokus Media.

Wignjoseobrotto S (2008) Hukum dalam Masyarakat: Perkembangan dan Masalah, sebuah Pengantar ke Arah Kajian Sosiologi Hukum. Malang: Bayu Media.

Zuhro RS, Mulyano L, Fotria, \& Prasojo E (2010) Kisruh Perda: Mengurai Masalah dan Solusi. Yogyakarta: The Habibie Center. 